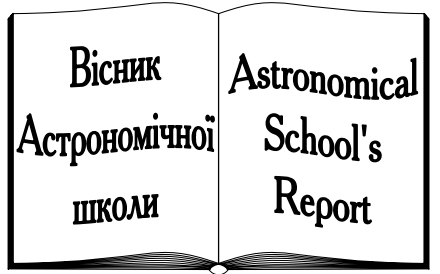

ISSN 2411-6602 (Online)

ISSN 1607-2855 (Print)

Volume $15 \bullet$ Issue $1 \bullet 2019 \quad$ P. $7-10$

https://doi.org/10.18372/2411-6602.15.02

UDC 528.85

\title{
Temporal variations of the Black Sea level from remote sensing data
}

\section{G.A. Frolov*, V.Yu. Belenok}

National Aviation University, Kosmonavta Komarova Avenue 1, 03058 Kyiv, Ukraine

The temporal changes in the level of the Black Sea were studied using statistical analysis of Black Sea surface level anomalies measurements. Off-season variations of Black Sea level were shown. Three maxima of the sea level temporal curve were found in 2010, 2013 and 2016. Correlation analysis was performed as well as a linear regression graph was plotted for average sea level anomalies and average sea surface temperature over the observation period (2008-2017). The spatial correlation between SLA and SST was found earlier. Using spatio-temporal data, we study the temporal correlation here. A weak temporal correlation is revealed.

Keywords: Black sea level variations; correlation analysis; Earth remote sensing; Geo-Information Technologies; mean sea surface; satellite altimetry; sea level anomaly; sea surface temperature.

\section{INTRODUCTION}

The study and monitoring of the Earth from space is becoming increasingly relevant with the space technologies development. This is due to a sufficiently large satellite coverage area, the speed of obtaining and the reliability of the data obtained.

Satellite altimetry is one of the active methods of remote sensing of the surface from a spacecraft. The distance from the satellite to the underlying surface is calculated by the return time of the probing radio pulse, which makes it possible to determine the height of the sea surface.

There is a large number of altimetric satellites in outer space. All of them have sufficient accuracy to investigate the marine geoid and the influence of underwater relief elements on it.

Systematic observations of the change in the Black Sea level began in the nineteenth century. Currently, it is possible to carry out surveillance directly using satellites.

The spatial correlation between SLA (sea level anomaly) and SST (sea surface temperature) was found earlier [11]. Using spatio-temporal data, we study the temporal correlation here. The main objective is to monitor the level of the sea surface using satellite altimetry data and geospatial technologies for studying general trends of increasing the Black Sea surface heights during the observation period (2008-2017).

\section{ALTIMETRIC DATA PROCESSING}

"Copernicus" (CMEMS) is marine environment monitoring service, that provides regular and systematic reference information on the physical and biogeochemical state, variability and dynamics of the ocean and marine ecosystems for the global ocean and the European regional seas. These data are publicly available on the CMEMS website.

Copernicus is the European Union's Earth Observation Programme, looking at our planet and its environment for the ultimate benefit of all European citizens. It offers information services based on satellite Earth Observation and in situ (non-space) data. CMEMS operating normally from May 2015.

The Copernicus Marine Service has been designed to respond to issues emerging in the environmental, business and scientific sectors. CMEMS provides daily analyzes and forecasts that provide an opportunity to observe, understand and anticipate various events that could time-to-time or abruptly occur in the marine environment [1]. Monitoring and understanding of sea level variations at various spatial and temporal scales have been the focus of many studies during the past decades [2]. The study of the surface level variations of the World Ocean waters consists in the use of satellite mission data, whose spacecraft are equipped with a special instrument - an altimeter. Satellite altimetry is one of the active methods of remote sensing of the surface from a spacecraft.

Altimetry is basically a technique for measuring height. Satellite radar altimetry measures the time taken by a radar pulse to travel from the satellite antenna to the surface and back to the satellite receiver. Moreover, this measurement yields a wealth of other information that can be used for a wide range of applications [3].

A satellite altimetry system includes a radar to measure the height of a satellite above the earth's surface and a tracking system to determine the height of a satellite in a geocentric coordinate system. The system measures the sea level rise relative to the center of mass of the Earth. Thus sea surface form can be obtained.

*Frolov Gleb Aleksandrovich; $₫$ saintmer4ant@gmail.com 
Satellite altimetry method was originally designed for open ocean conditions at a distance from the coast at least $20 \mathrm{~km}$, where it provides accurate measurements stated [4].

The Copernicus Space Component includes the ESA's "Sentinels" and the Contributing Missions, which are operated by national, European or international organisations and already provide a wealth of data for Copernicus services. Among the altimetry missions, it is worth mentioning Saral / Altika, EnviSat, the Topex / Poseidon project and the Jason satellites family, the measurements of which were used to compile a single netCDF dataset.

Nowadays there are several ways to display altimetric data in netCDF format in the Windows software environment: using web services (AVISO, My NASA Data), using programming as well as using specialized software (like Panoply). However, AVISO, My NASA Data web services, and Panoply allow to view a set of altimetry data, but there is no possibility of statistical analysis. This problem is solved with by using a programming language. We use Matlab and Python programming to preprocess the satellite altimetry data set.

From the above, it can be concluded that these software tools and satellite altimetry data sets presented on web resources can be used for statistical analysis of temporal changes in the sea surface level. The accuracy and spatial resolution of satellite altimetry data depends primarily on the altimeter used on board the spacecraft.

\section{TEMPORAL VARIATIONS}

As a source of initial data, a netCDF file from the CMEMS site was taken for the purpose of statistical analysis of the temporal changes in the Black Sea level over the observation period (2008-2017). The CMEMS website has the ability to download a dataset in a vector format, as well as the ability to download a netCDF file, in which the optimal interpolation of values was previously performed. The initial spatial resolution is $0.125 \times 0.125$ arc degrees, which is sufficient for conducting a statistical analysis of the temporal changes in the Black Sea level, as well as assessing the correlation of average values of the Black Sea level anomalies and average values of the Black Sea surface temperature in a certain period of time.

The netCDF satellite altimetry file used in this article contains the Black Sea level anomalies (SLA) as an array of data over the observation period (2008-2017). The SLA can be defined as the difference between the sea surface heights (SSH) and the long-term mean sea surface (MSS) heights. The SSH is calculated using altimetry satellites, which determine the difference between satellite's height (it is known) and SSH (above reference ellipsoid) by measuring the satellite-to-surface round-trip time of a radar pulse. SLA is considered a valuable proxy for detecting long-term changes of the global ocean and SSH variations [5].

In this article, daily SLA grids for the period 2008-2017 are used to characterise Black Sea level variability at inter-annual timescales. Dataset reference coordinate system is WGS-84. The dataset contains averaged SLA values relative to the average SLA null over the year 1993.

The observations show that the Black Sea circulation has strong seasonal variations [9]. To display the dynamics of the Black Sea surface level off-season variations over the observation period (2008-2017), a graph, shown in Fig. 1, was drawn. Spatial-aggregation method used in this article is the reduction of the data array to one mean value over the whole surface. The Black SLA was presented as the ordinate axis, and the period of observations of these deviations as the abscissa axis. The average height of the SLA on the graph was displayed in centimeters. This chart takes into account the off-season Black Sea level variations. Relative deviations were calculated using a sliding window algorithm with a size of 365 days. The average value for 2008 was submitted as the first value on the graph and related to mid-2008.

Based on [6], on the authors constructed plot (Fig. 1) the trend changes of the Black Sea level was calculated and plotted. The graph of average off-season variations of the Black Sea level (Fig. 1) revealed the absence of negative SLA values, which indicates an increase in the level of the Black Sea surface relative to the sampling (i.e. to the average SLA null over the year 1993), and also some "jumps" in the average SLA values were found, the frequency of which is about $2-3$ years approximately.

The averaging of the Black Sea level anomalies values by days was used to perform statistical analysis.

The data on sea surface temperature help to facilitate our understanding of the global dynamics and processes that take place in the waters of the oceans. SST data are measured through satellite remote sensing using microwave (infrared) wavelength.

The brightness temperature only characterizes the radiation and, depending on the radiation mechanism, may differ significantly from the physical temperature of the "radiating" body [7].

The highest available spatial data on the temperature of the ocean's surface resolution of the last time is about $1 \mathrm{~km}$ that was obtained by MODIS measuring instruments. NOAA's Aqua satellite measurements were obtained using this spectroradiometer. It also was converted to temporal data and represented on Fig. 2.

To observe the correlation between SLA and SST, off-season surface temperature data of the Black Sea were visualized (Fig.2) in order to calculate the correlation coefficient between the SLA and SST values. The SST in Fig. 2 is presented in Kelvins. 


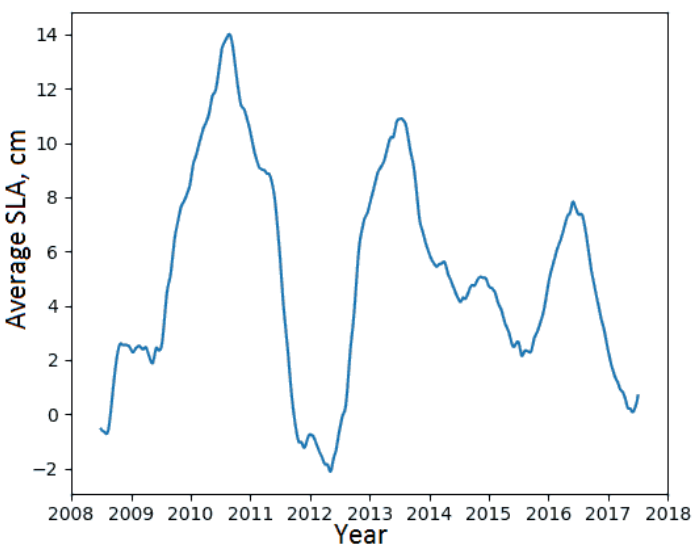

Fig. 1. Daily average SLA deviations relatively the sampling with correction for season variations over the observation period (2008-2017)

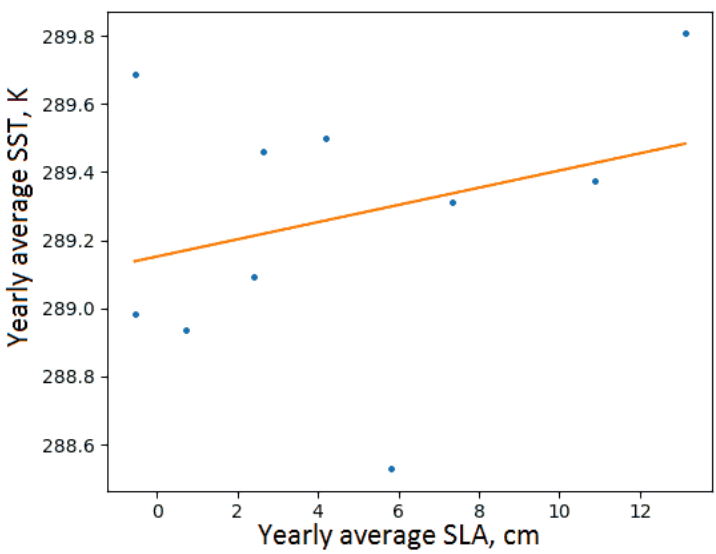

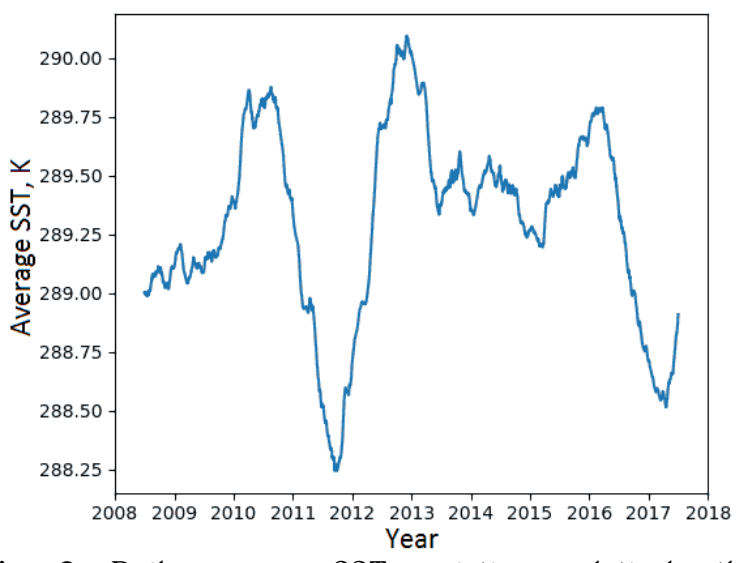

Fig. 2. Daily average SST variations relatively the sampling with correction for season variations over the observation period (2008-2017)

As we can see, Fig. 1 and Fig. 2 have similar features (three maxima and the deep minimum, in 2011). The causes of the delay between those values will be investigated in the following studies.

Fig. 3 shows the linear regression graph of the yearly average SLA and SST over the observation period (average for the year). The correlation coefficient $r$ was 0.31 , which indicates a weak correlation between the off-season temporal average Black SST and its surface level off-season variations.

\section{CONCLUSIONS AND PROSPECTS FOR FURTHER RESEARCH}

This article presented the result of a statistical analysis of Black Sea surface level anomalies data.

The graph of average Black sea level deviations (Fig. 1) shows the absence of negative average SLA values, which indicates an increase in surface level of the Black Sea relatively the sampling, as well as indicates the presence of some "jumps" in the average SLA values over the observation period, the frequency of which is about 2-3 years approximately. The global mean sea level rise makes coastal communities and ecosystems particularly vulnerable to local sea level fluctuations [10].

The weak effect of sea surface temperature change on the dynamics of Black Sea level variations was found, and a linear regression graph was plotted (Fig. 3).

The data used in this article are taken from open sources, and the presented results can be used for further research in order to prevent extreme situations in the coastal zone, to ensure the relative balance of the oceans, to study the effect of global ocean warming phenomenon on Black Sea surface level, etc. [8].

Acknowledgements. We would like to show our gratitude to Velikodsky Yu.I. from National Aviation University of Ukraine for his valuable support during of this research, and we thank two anonymous reviewers for their advice and insights.

1. Copernicus marine environment monitoring service. - http://marine.copernicus.eu

2. Vergos G.S., Natsiopoulos D.A., Tziavos I.N. Sea level anomaly and dynamic ocean topography analytical covariance functions in the Mediterranean sea from ENVISAT data // 20 Years of Progress in Radar Altimatry, held 24-29 September, 2013 in Venice, Italy.

3. Rosmorduc V., Benveniste J., Bronner E., et. al. Radar Altimetry Tutorial. - European Space Agency, 2016.

4. Марченко О.М. Визначення геоїда, поля сили тяжіння та топографії Чорного моря за даними супутникової альтиметрії // Геодезія, картографія і аерофотознімання. - 2015. - № 81. - С.46. 
5. Iglesias I., Nieves Lorenzo M., Lázaro C., et. al. Sea level anomaly in the North Atlantic and seas around Europe: Long-term variability and response to North Atlantic teleconnection patterns // Science of the Total Environment. - 2017. - Vol.609. - P.861. https://doi.org/10.1016/j.scitotenv.2017.07.220

6. Zatserkounny V.I., Babych Y.V., Belenok V.Yu., Frolov G.A., Hebryn-Baydi L.V. Black sea level change monitoring using altimetry data and geoinformation technologies // XVIII International Conference on Geoinformatics - Theoretical and Applied Aspects, 13-16 May 2019, Kiev, Ukraine.

https://doi.org/10.3997/2214-4609.201902060

7. Беленок В.Ю., Фролов Г.О. Використання дистанційного зондування Землі для дослідження мінливості температури поверхні Світового океану // XXI Міжнародна наукова конференція «Астрономічна школа молодих вчених. Актуальні проблеми астрономії і космонавтики» (Україна, Колочава, 21-23 травня 2019 р.). Програма і тези доповідей. - С.6.

8. Беленок В.Ю., Фролов Г.О. Використання штучних супутників для дослідження динаміки зміни висоти морської поверхні // XXI Міжнародна наукова конференція «Астрономічна школа молодих вчених. Актуальні проблеми астрономії і космонавтики» (Україна, Колочава, 21-23 травня 2019 р.). Програма і тези доповідей. - C.7.

9. Korotaev G.K., Saenko O.A., et. al. Satellite altimetry observations of the Black Sea level // Journal of Geophysical Research: Oceans. - 2001. - Vol. 106 (C1). - P.917-933.

https://doi.org/10.1029/2000jc900120

10. Volkov D.L., Johns W.E., et. al. Dynamic response of the Black Sea elevation to intraseasonal fluctuations of the Mediterranean sea level // Geophysical Research Letters. - 2016. - Vol. 43 (1). - P.283-290. https://doi.org/10.1002/2015gl066876

11. Lebedev S.A., Kostianoy A.G., Bedanokov M.K., Akhsalba A.K., Berzegova R.B., Kravchenko P.N. Climate changes of the temperature of the surface and level of the Black Sea by the data of remote sensing at the coast of the Krasnodar Krai and Republic of Abkhazia // Ecologica Montenegrina. 2017. - Vol. 14. - P.14-20.

\section{Часові варіації рівня Чорного моря за даними дистанційного зондування \\ Фролов Г.А., Беленок В.Ю.}

Національний авіаційний університет, 03058, м. Київ, пр. Космонавта Комарова, 1

В роботі на основі статистичного аналізу вимірювань аномалій рівня поверхні Чорного моря було досліджено часові зміни рівня поверхні Чорного моря протягом періоду спостережень 2008-2017 рр. В даній статті було виконано просторову агрегацію даних коливань рівня Чорного моря шляхом зменшення масиву даних до одного середнього значення по всій поверхні. 3 вихідних альтиметричних даних було вилучено сезонні варіації з метою відображення позасезонного тренду, після чого було проведено кореляційний аналіз. В ході роботи було побудовано графік лінійної регресії для значень середніх аномалій рівня морської поверхні (SLA) і значень середньої температури морської поверхні (SST) за період 2008-2017рр. Графік середніх відхилень рівня Чорного моря показує майже повну відсутність негативних середніх значень SLA, що вказує на підвищення рівня поверхні Чорного моря відносно вибірки. Просторову кореляцію між SLA та SST було досліджено раніше. У даній роботі, використовуючи просторово-часові дані, було вивчено часову кореляцію. В результаті було виявлено три максимуми часової кривої відносного рівня моря, що вказує на деяку періодичність “стрибків” рівня Чорного моря, частота повторення яких складає приблизно 2-3 роки. Аналіз даної періодичності буде проведений в наступних роботах. Також було показано, що часова кореляція середніх значень SLA та SST є слабкою.

Ключові слова: варіації рівня Чорного моря; кореляційний аналіз; дистанційне зондування Землі; геоінформаційні технології; середня морська поверхня; супутникова альтиметрія; аномалія рівня моря; температура поверхні моря.

\section{Временнь́е вариации уровня Черного моря по данным дистанционного зондирования} Фролов Г.А., Беленок В.Ю.

Национальный авиационный университет, 03058, г. Киев, пр. Космонавта Комарова, 1

В статье на основе статистического анализа измерений аномалий уровня поверхности Черного моря исследованы временные изменения уровня поверхности Черного моря и отображен внесезонный тренд, а также проведен корреляционный анализ и построен график линейной регрессии для значений средних аномалий уровня морской поверхности и значений средней температуры морской поверхности в течение периода наблюдения (2008-2017). Пространственная корреляция между SLA и SST была обнаружена ранее. Используя пространственно-временные данные, мы изучаем временную корреляцию. Обнаружены три максимума временной кривой относительного уровня моря, а также показано, что временна́я корреляция является слабой.

Ключевые слова: вариации уровня Черного моря; корреляционный анализ; дистанционное зондирование Земли; геоинформационные технологии; средняя морская поверхность; спутниковая альтиметрия; аномалия уровня моря; температура поверхности моря. 